\title{
An Empirical Investigation of the Effect of Interaction Justice Perception on Consumer Intentions After Complaining
}

\author{
Mahesh S. Bhandari and Michael J. Polonsky \\ Victoria University, Australia
}

\begin{abstract}
This study examined how apology as interaction justice impacts on consumer perceptions of service recovery attempt. Data was collected using hypothetical scenarios. Two types of service failures were proposed and the impact of recovery action on each failure type was compared. Findings include that there is direct effect of recovery action on consumer future intentions in both type of failures. Implications and direction to the future research were proposed.
\end{abstract}

\section{Keywords}

Marketing and Sales

\section{Introduction}

Organisations are at more risk of losing customers because of increased competition in the market place. This is further increased especially when customers experience service failure (Zemke and Bell, 1990). Competition reduces the costs of switching providers, which in turn reduces market share and profitability of those service providers who lose these customers (Keaveney, 1995). It has been suggested that customer switching, as a result of service failure, can be prevented if organisations undertake effective service recovery processes (Hart, Hesket and Sasser, 1990; Bailey, 1994). According to Tax, Brown and Chandrashekaran (1998), existing customers may still be ready to repurchase if their complaints are properly attended. As such, service firms must ensure that once they attract customers they should also undertake activities to keep those customers in a regular business (Andreassen, 2001).

The intangible nature of service makes service failure inevitable. However, literature suggested the option of service recovery to the service providers. Boshoff (1998) indicated that effective service recovery processes allow service firms to turn dissatisfied customers into satisfied ones. In relation to the effectiveness of service recovery actions, justice perceptions appear to be associated with consumer future intentions (Mattila 2001; Sparks and McColl-Kennedy 1998). Services are process where consumer involvement is inevitable in most encounters. Therefore, interactional justice perception is likely to be the most influencing one on

Copyright (C) 2007 Victoria University. This document has been published as part of the Journal of Business Systems, Governance and Ethics in both online and print formats. Educational and non-profit institutions are granted a nonexclusive licence to utilise this document in whole or in part for personal or classroom use without fee, provided that correct attribution and citation are made and this copyright statement is reproduced. Any other usage is prohibited without the express permission of the consumer future intentions (Wirtz and Mattila 2004).

There are a number of consumer future intentions mentioned in the literature which may vary with consumers' negative service experience. This includes both behavioral and cognitive attitudes such as referrals (Dabholkar and Verby 2004), repurchase 
(Bamford and Xystouri 2005), loyalty (Ndubishi and Ling 2006), satisfactions (Barnes and Eagle 2004) and expectations (Writz and Mattila 2004). Existing literature intended to investigate these consumer intentions following service failure, and the majority of studies seem to agree that consumers will generally have negative evaluation about the service organisation if the service delivery process fails. However, only limited studies attempted to identify the variations in justice perception when consumers and employees interact with each other while attempting to rectify the problems (Bhandari and Polonsky 2004). This study aimed to explore the possibilities of improvement in negative consumer intentions triggered by negative perception of service delivery.

\section{Consumer Complaining}

The comparison of pre-purchase expectations and post-purchase outcome leads to situations of either confirmation or disconfirmation (Lovelock, Patterson and Walker 2004). When a customer finds that the post-purchase outcome is not similar to what was expected, disconfirmations occurs (James, 2003). In such conditions, satisfaction results from how well the actual service performance, in other words the service process and outcome, matches the customer's expectations (Jukka, 2001). If service performance is below expectation it will be a negative disconfirmation and customers are more likely to complain (Snellman, 2000).

Complaining customers are among the most loyal customers (Tax et al., 1998). Complaining also indicates that customers are willingness to remain in business with the current organisation (Patterson 2001). Research also indicated that customers who complain are also more likely to repurchase, even when their complaint is not handled satisfactorily (Zekme and Bell, 1990). If the problem is resolved they will tell even more people about this successful recovery than if they had received 'good' service in the first place (Brown, 2000).

\section{Service Failure and Recovery}

Although the concept of service failure is relatively new, recent trends show that it is one of the main topics of research within services marketing. Defined as 'the specific event that occurs when service providers do not fulfil their promise to the customers, researchers seem to agree that service failure is inevitable. A recent study of Zhu, Shivkumar and Parasuraman (2004) further indicated that service failure can be of two types; process and outcome failure. Further, customers react to the service failure in various ways such as complaining, seeking redress, negative voice responses and stopping business relationships with the service organisation. Meaning that customers have willingness to express dissatisfaction as well as take some actions if they are not happy with what they received. In addition unsatisfactory service experience could also affect customer loyalty. Therefore, to keep customers in regular business, service organisations need to overcome the negative impact of poorly performed service. In other words, organisations need to have a process of corrective actions know as service recovery. There are a range of strategies that a firm can implement as service recovery actions such as, apology and compensation. However, apology is regarded as the most important action to improve consumer perception of interaction fairness. Zemke and Bell (1990, p. 44) were first to highlight the importance of apology in service recovery strategy. They stated, "When disconfirmation does occur, most consumers want the service they were promised in the first place, along with some personal attention and a decent apology". They suggested that the reason why people take the trouble to complain is that they only want what they were denied. Further Eccles and Durand (1998) suggested that this can be managed by a simple apology. Meaning; if a company fulfils the needs of a complaining customer then this individual will reciprocate by continuing to do business.

Boshoff and Leong (1997 p 42) also identified the importance of apology for three reasons. First, it can be done quickly and, in this way, reduce the customer's anxiety. Second, it conveys to the customer that the problem is being attended to and that the firm cares about them and their wellbeing. Third, a complaining customer is often an angry customer. An apology can, at least to some extent, defuse that anger and curb the possible harmful effects of service failure such as negative word-of-mouth (WOM). 
An apology is recognition that the customer has been inconvenienced and enhances the possibility of a continued relationship (Zemke and Bell, 1990). This is more effective when accompanied by some tangible token of restitution (Conlon and Murray, 1996; Goodwin and Ross, 1992).

An apology can take various forms, (Boshoff and Leong 1998). One alternative is a telephone apology, which offers the advantages of speed and reasonable cost-effectiveness while still retaining a sizeable personal element. A letter, on the other hand, is less costly but lacks the ability to demonstrate sincerity and authenticity (Bell and Ridge, 1992). Both Zemke (1994, p. 17) and Bell and Ridge (1992, p. 61) argue, however, that a personal apology is best because it offers the opportunity to demonstrate that the firm understands the frustration of being inconvenienced.

\section{Consumer Future Intentions}

Literature seems to suggest that consumers' behavioural and cognitive responses can vary with service recovery activities. Firstly, WOM has been identified as an important post-purchase behaviour for several reasons (Day1980). Several services marketing researchers have considered the word-of-mouth intentions associated with service encounters e.g., Parasuraman, Zeithaml, and Berry (1988). Word of mouth communication provides face-to-face, often vivid information that is highly credible (Liu, Sudharshan and Hamer 2000).

Secondly, Loyalty is one of the responses a customer has to a service failure. Loyalty is a build through a series of successful service encounters over a long period of time. But it is widely recognised by service marketers that loyalty generated through enormously successful service delivery attempts can be lost with few negative service experiences (Reichheld and Sasser 1990). Therefore effective service recovery could be the means of regaining customer loyalty and hence the likelihood of remaining in the business (Jones and Sasser 1995).

Thirdly, variation in complaint intentions with service failure is indicated by various researchers (e.g. Edvardsson and Roos 2003; Heung and Lam 2003; Hocutt et al., 2006; Kim et al., 2003; Lee and Hu 2004). However, literature search shows that the complaining intentions following a service failure are yet to be examined (Maxham and Netemyer 2003; Schoefer and Ennew 2004). This is probably because service firms intend to assume a customer is identical to a satisfied customer once a complaint is attended to satisfactorily (Eccles and Durand 1998; Stauss 2002). Knowing that complaints are the most useful and meaningful source of information to improve customer service, it is essential to examine complaining intentions as post recovery intentions of a customer who encountered a service failure (Heung and Lam 2003).

Fourthly, customer satisfaction is the primary focus of service organisations. This is however, limited to the initial service delivery (eg, Reichheld and Sasser, 1990). More recent empirical studies indicated that overall satisfaction is essential to the service organisations (Kanousi 2005; Hoffman et al., 2003 and Snellman and Vihtkari, 2003).

Fifth, a customer is assumed to have expectations regarding service performance, and these expectations are compared with actual perceptions of performance as the service is consumed (Swanson and Kelley 2001). When expectations are not met, it could lead to customer defection and their future expectations could be changed with lower quality of service performed.

Another important consumer decision based on service performance and corresponding customer perception is intention to switch a service provider. Service switching is one of the most prominent outcomes of service failure (Keaveney 1995). Considerable efforts in service research have been given to identify the reason for customers switching service providers (eg. Keaveney 1999; Reardon and McCorkle 2002).

Although research findings agree that switching of service providers has multiple damaging effects on the firm including reductions in market share and profitability (Lewis and Spyrakopoulos 2001), only 
few attempts are made to investigate how a decision once made would vary with a service recovery effort in regards to these switching intentions.

Finally, intention to repurchase is another important consumer outcome (Bamford and Xystouri 2005). Although repurchase intentions following a service experience are well researched, the strategy to get a customer back to the business, or Customer "winback" strategies, are neglected in the service marketing literature (Thomas et al., 2004). Customer winback is the process of firms' revitalising relationships with customers who have defected (Griffin and Lowenstein 2001). Similarly, Grace and O'Cass, (2001) and Keaveney (1995) found that repurchase intentions can be increased when effective service recovery activities are undertaken. In addition, Ranaweera and Prabhu (2003), Zemke and Bell (1990) and Johnson and Fern (1999) all suggested that consumers' repurchase intentions vary depending on organisational and/or employee recovery actions. Thus the intention to repurchase from a service provider is an important measure of service recovery effectiveness (Palmer et al. 2000).

\section{Interaction Justice}

Service literature included impact of justice perceptions to explain consumer complaint behaviour (Hoffman and Kelly 2000; Tax et al., 1998). One of the prominent justice considerations is in regards to interaction fairness (Poon et al. 2003). Lovelock et al. (2001) defined interactional justice as the way people are treated during a complaint. A recent study of Writz and Mattila (2004) indicated interaction justice perception to the apology offered by service employees. Interaction fairness when perceived as favourable by the consumer has a positive effect on consumer future intentions such as re-patronage decisions and a negative effect on negative word-of-mouth. Together with this, a framework of service recovery (Figure 1) and hypotheses are proposed:

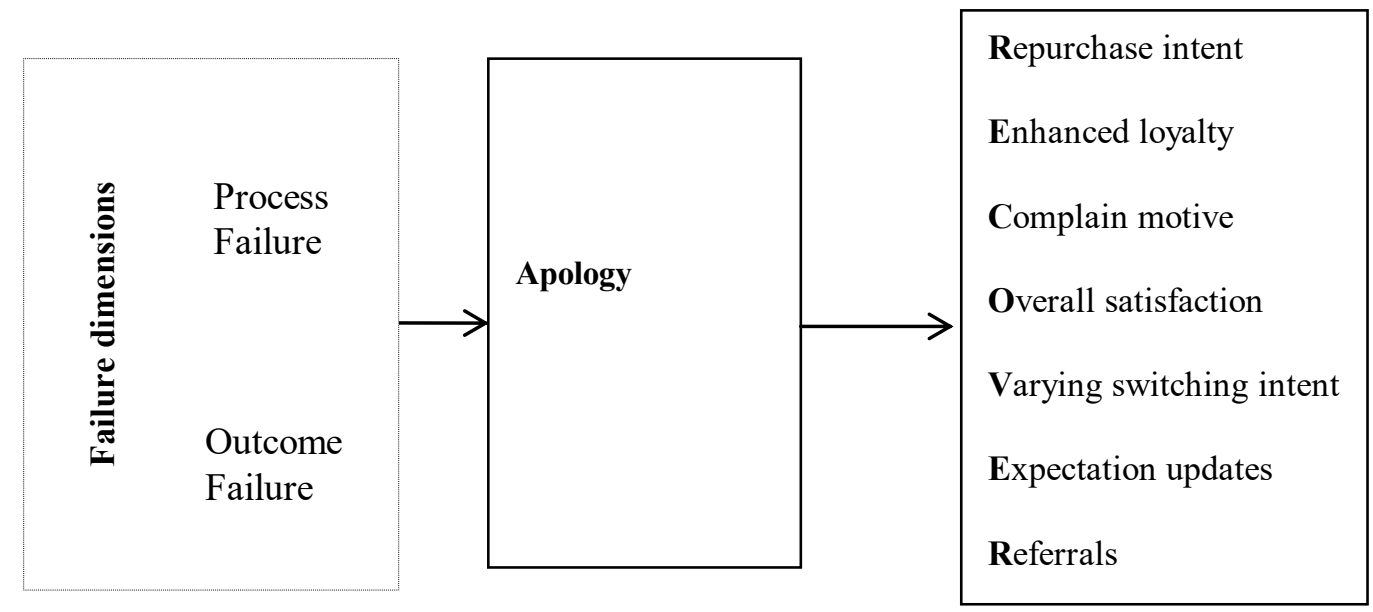

Figure 1: A framework of service recovery

H1.1 Offering (not offering) apology to a customer during process failure recovery will have the same effect on a) complaint motives and b) future expectation from the service provider to that of outcome failure recovery.

H1.2 Offering (not offering) apology to a customer during process failure recovery will have same effect on a) word of mouth referrals b) consumer loyalty c) repurchase intentions d) overall satisfaction and e) switching intentions to that of outcome failure recovery.

\section{The Investigation}

This research is an experimental study conducted on the responses of participants on 32 hypothetical scenarios. An experimental study is the investigation in which independent variables can be manipulated to test a hypothesis about a dependent variable in controlled conditions (Zikmund 2003). The controlled situations helped to evaluate the causal relationship among variables. This study consisted of 
randomised block design. It has the benefit of increased efficiency as compared to the completely randomised design.

The respondents were provided a hypothetical scenario (Boshoff 1998, Wason et al. 2002). Scenario based studies in the service recovery area were conducted more frequently in the recent past. Several reasons are cited within the literature indicating superiority of scenarios over the conventional survey methods. For example, a scenario does not require respondents to recall the real incident (Wirtz and Mattila 2004); a scenario controls all extraneous variables otherwise uncontrollable (Swanson and Kelley 2001); the resemblance of scenarios with real incidents can be tested with a realism test (Kanousi 2005). Within the scenarios of this study, apology was varied as 'apology offered' and 'apology not offered'. The scenario examined focused on a hotel visit in which participants were asked to assume the situation explained in it had happened with them before completing the survey. An example scenario is included below.

"....You are travelling on an important business trip. You arrive at the hotel at $10 \mathrm{pm}$ after having travelled the whole day. The desk clerk looks up your prepaid reservation on the computer and informs you that your room is ready. However, when you get to your room, you find that the room has not been cleaned. You call the desk clerk and say that you want a clean room. The desk clerk indicates that he cannot fix it himself. They will have to ask the manager how to proceed. The manager contacts you and indicates that he will send up a porter to move you to a new room. The Manager explains that there is a large conference in town and they have faced unanticipated demand, with people checking out late or wanting to stay an extra day. They go on to say that these things happen in big organisations. You ask whether you will be compensated for the inconvenience. The Manager indicates that the hotel will organise for you to be credited with a free nights stay on another visit."

Prior to distributing the survey to hotel guests we undertook in-depth interviews with eight hotel managers to ensure realism of the scenarios with real world recovery incidents identical to the method applied by Ruyter and Wetzels (2000). In addition a sample of university students were asked rate the hypothetical incidents as suggested by Swanson and Kelley (2001). They had a mean rating of 8.1 that indicate manipulations are highly effective (Writz and Mattila 2004). The composite dependent items were measured with 7 point Likert type scale.

A pre-test of the survey was conducted with 32 employees of a hotel to ensure face validity. The data collection for the final study followed the propose proposed by Lewis and Spyrakopoulos (2001) whereby 80 hotel guests (46 female and 34 male) visiting one Melbourne hotel were selected to complete a version of the survey in which one service failure scenario was provided. The highest numbers of participants were between age 18 and 30 years (more than 45\%) followed by 31 to 40 years $(38 \%)$. A block analysis was used, where 20 valid responses were sought for each block before changing the scenario (Johnston and Fern 1999). A reliability test was conducted to identify the overall reliability of dependent measures and all variables were within acceptable criteria with the alpha value equal to or higher than 0.66 (Kivela et al. 2002).

The result of manipulation check indicated that our manipulations were correct. Data analysis was carried out with ANOVA to examine the effects of apology in both process failure and outcome failure situations. Table 1 summarises the effects of apology (vs. no apology) in process failure situation.

\begin{tabular}{|c|c|c|c|c|c|c|}
\hline Dependent variables & \multicolumn{3}{|c|}{ Process Failure } & \multicolumn{3}{c|}{ Outcome Failure } \\
\hline & $\begin{array}{c}\text { Apology } \\
\text { offered }\end{array}$ & $\begin{array}{c}\text { Apology } \\
\text { not offered }\end{array}$ & t-value & $\begin{array}{c}\text { Apology } \\
\text { offered }\end{array}$ & $\begin{array}{c}\text { Apology } \\
\text { not } \\
\text { offered }\end{array}$ & t-value \\
\hline & & & & & & \\
\hline ExUpdate & 5.8036 & 5.8366 & $\begin{array}{c}-.909 \\
(\mathrm{p}=.364)\end{array}$ & 5.7360 & 4.3998 & $\begin{array}{c}42.863 \\
(\mathrm{p}<.000)\end{array}$ \\
\hline ComMotive & 4.9175 & 5.0735 & -3.324 & 5.2338 & 4.2468 & 32.895 \\
\hline
\end{tabular}




\begin{tabular}{|l|l|l|l|l|l|l|}
\hline & & & $(\mathrm{p}=.001)$ & & & $(\mathrm{p}<.000)$ \\
\hline
\end{tabular}

Table 1: T-test for the effect of apology (vs. no apology) on process failure

Under the process failure, the effect apology vs. no apology on expectation updates was insignificant $(\mathrm{M}=5.80$ vs. $\mathrm{M}=5.83 ; \mathrm{t}=-.909, \mathrm{p}<.364)$. However, this effect was significant in outcome failure $(\mathrm{M}=5.73$ vs. $\mathrm{M}=4.39 ; \mathrm{t}=42.8, \mathrm{p}<.000)$. On the other hand the difference in complaining intentions was significant in both process failure $(\mathrm{M}=4.91$ vs. $\mathrm{M}=5.07 ; \mathrm{t}=-3.32, \mathrm{p}=.001)$ and outcome failure $(\mathrm{M}=5.23$ vs. $\mathrm{M}=4.24 ; \mathrm{t}=32.89, \mathrm{p}<.000)$. However, this significant difference was not unidirectional ( $\mathrm{t}=-3.32$ vs. $\mathrm{t}=+32.8$ ). This indicated that consumer intentions to complaint were higher when apology not offered in process failure while complaining intentions were lower in outcome failure situations (Table 1). Together, theses results do not support H1.

\begin{tabular}{|c|c|c|c|c|c|c|}
\hline Dependent variables & \multicolumn{3}{|c|}{ Process Failure } & \multicolumn{3}{c|}{ Outcome Failure } \\
\hline & $\begin{array}{c}\text { Apology } \\
\text { offered }\end{array}$ & $\begin{array}{c}\text { Apology } \\
\text { not offered }\end{array}$ & t-value & $\begin{array}{c}\text { Apology } \\
\text { offered }\end{array}$ & $\begin{array}{c}\text { Apology } \\
\text { not } \\
\text { offered }\end{array}$ & t-value \\
\hline RepIntent & 4.1944 & 3.4601 & $\begin{array}{c}14.809 \\
(\mathrm{p}<.000)\end{array}$ & 3.7217 & 3.0297 & $\begin{array}{c}22.180 \\
(\mathrm{p}<.000)\end{array}$ \\
\hline OvrSatis & 4.6938 & 3.7408 & $\begin{array}{c}18.024 \\
(\mathrm{p}<.000)\end{array}$ & 4.2390 & 3.4674 & $\begin{array}{c}25.041 \\
(\mathrm{p}<.000)\end{array}$ \\
\hline EnhLoyalty & 3.8425 & 3.3207 & $\begin{array}{c}10.329 \\
(\mathrm{p}<.000)\end{array}$ & 3.4415 & 3.0039 & $\begin{array}{c}14.535 \\
(\mathrm{p}<.000)\end{array}$ \\
\hline WoM & 4.2781 & 3.3875 & $\begin{array}{c}23.326 \\
(\mathrm{p}<.000)\end{array}$ & 4.1259 & 3.5625 & $\begin{array}{c}20.712 \\
(\mathrm{p}<.000)\end{array}$ \\
\hline VaySwtInt & 4.0725 & 4.1833 & $\begin{array}{c}-2.733 \\
(\mathrm{p}=.006)\end{array}$ & 3.7809 & 4.2503 & $\begin{array}{c}-18.302 \\
(\mathrm{p}<.000)\end{array}$ \\
\hline
\end{tabular}

Table 2: T-test for the effect of apology (vs. no apology) on outcome failure

In regards to $\mathrm{H} 2$, Table 2 shows the significant difference in repurchase intentions $(\mathrm{M}=4.19$ vs. $\mathrm{M}=3.46 ; \mathrm{t}=14.8, \mathrm{p}<.000)$, overall satisfaction ( $\mathrm{M}=4.69$ vs. $\mathrm{M}=3.74 ; \mathrm{t}=-18.04, \mathrm{p}<.000)$, loyalty $(\mathrm{M}=3.34$ vs. $\mathrm{M}=3.82 ; \mathrm{t}=10.32, \mathrm{p}<.000)$, word of mouth referrals $(\mathrm{M}=4.27$ vs. $\mathrm{M}=3.38 ; \mathrm{t}=23.32$, $\mathrm{p}<.000)$ and varying switching intentions $(\mathrm{M}=4.07$ vs. $\mathrm{M}=4.18 ; \mathrm{t}=-2.733, \mathrm{p}=.006)$. Four consumer future intentions; repurchase intentions, overall satisfaction, enhance loyalty and WoM referrals were significantly higher when apology was offered. However, switching intention was significantly lower when apology was not offered.

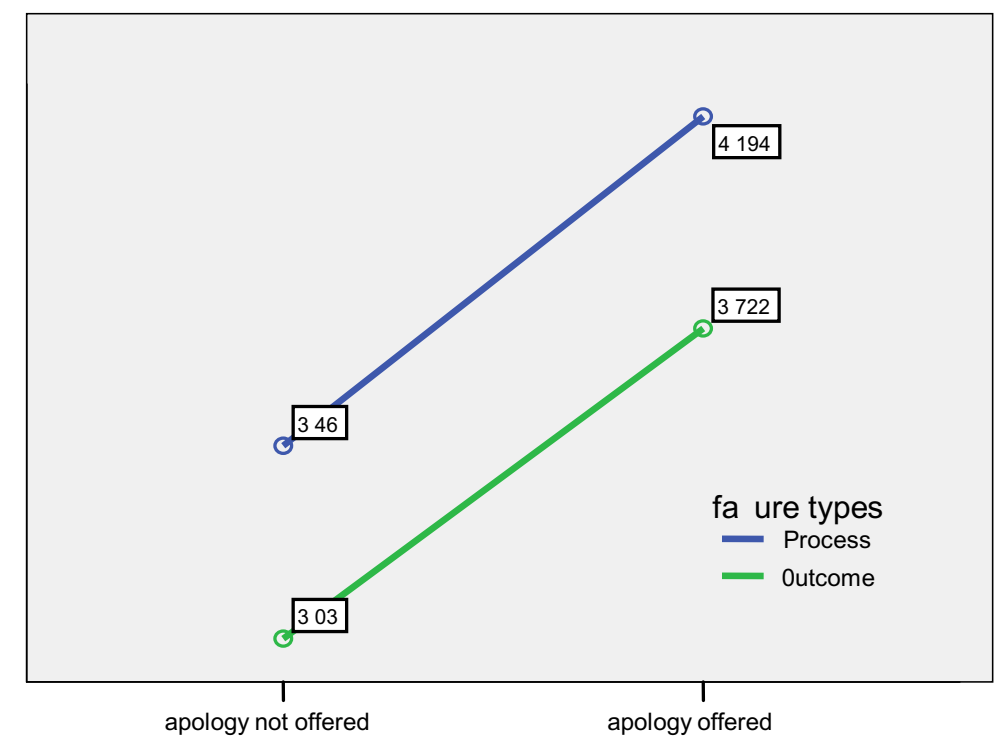

Figure 2: Effect of apology on repurchase intention in process and outcome failure 
The results for outcome failure were also identical (Table 2). The significant effect includes; repurchase intentions ( $\mathrm{M}=3.72$ vs. $\mathrm{M}=3.02 ; \mathrm{t}=22.18, \mathrm{p}<.000)$, overall satisfaction $(\mathrm{M}=4.23$ vs. $\mathrm{M}=3.46 ; \mathrm{t}=18.32$, $\mathrm{p}<.000)$, switching intensions ( $\mathrm{M}=3.78$ vs. $\mathrm{M}=4.25 ; \mathrm{t}=-18.36, \mathrm{p}<.000)$, loyalty $(\mathrm{M}=3.44$ vs. $\mathrm{M}=3.00$; $\mathrm{t}=14.53, \mathrm{p}<.000)$, switching intentions $(\mathrm{M}=3.78$ vs. $\mathrm{M}=4.25 ; \mathrm{t}=-18.30, \mathrm{p}<.000)$ and word of mouth referrals $(M=4.12$ vs. $M=3.56 ; t=20.71, p<.000)$. These results supported $H 2$. Some of the effect plots can be seen in figure 2 and 3 .

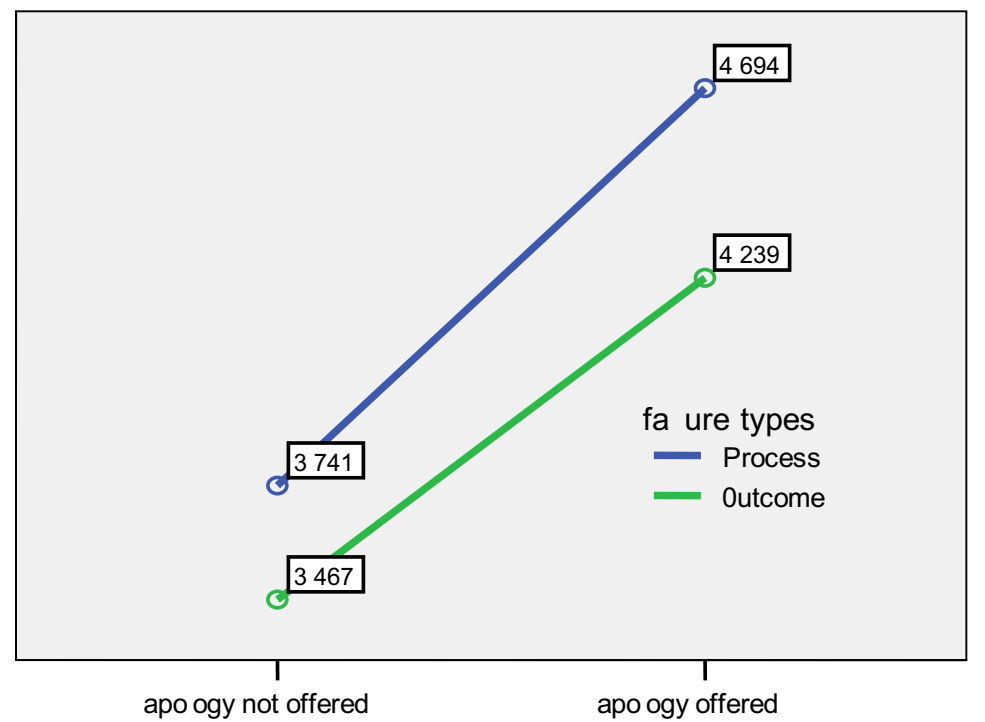

Figure 3: Effect of apology on overall satisfaction in process and outcome failure

\section{Implications and Conclusions}

This study highlights some important managerial implications by incorporating type of service failure and consumer future intentions. Firstly, the statistical evidence in regards to type of service failure indicated that effective service recovery strategy is important in both process and outcome failure situations. These results suggested that service organisations need to carefully consider whether service failure is perceived as process failure or outcome failure before designing service recovery processes.

Secondly, customer intentions appear to vary based on employee interaction justice. For example, while offering apology, the findings seem to suggest that consumers are more inclined to repurchase whereas switching intentions are higher when apology was not offered. However, offering apology seems ineffective in consumer future expectations from service provider and complaining intentions in process failure. On the other hand apology seems to have significant effect on them in outcome failure. This could possibly be because consumers tend to forget the negative service experience as long as the outcome failure is managed to their satisfaction. These findings put forward an important implication to the industry practitioners that they need to be aware of the role of offering apology while formulating service recovery strategy.

Although the results generally indicated an improvement in consumer outcomes with service recovery strategy, the variations of consumer future intention appear with complexity. Further, this study does not consider other salient issues such as consumer factors and the magnitude of failure. Therefore, organisations will need to consider the individual situation and consumer experiences. The implication of this is that organisations will be dependent on service staff for recovery actions. Staffs need to be provided with the appropriate training to be able to understand the impact of apology.

In addition to the important contributions to the service recovery literature as well as a range of implications to the service industry practitioners, this research also has some limitation. Firstly, the 
dependence on scenario-based experimentation is a major limitation in the area of service recovery research (Shapiro and Gonder 2006). Although this study was complimented by rigorous research with real customers as proposed by Maxham (2001), Shapiro and Gonder (2006), and Wirtz and Mattila (2004), scenario based research still lacks the real service encounters with real customers (Duffy et al., 2006) and real employees (Shapiro and Gonder 2006). Secondly, sample size in scenario based studies is generally small and this research in not an exception. While these approaches are supported in literature, inclusion of only 20 respondents per scenario could potentially limit the statistical power of the tests. Like previous studies, this study can also be replicated in real world failure situations with sufficient sample size as well as different industry settings. Thirdly, this research does not incorporates the gap model which is widely referred to across literature for effective management of customer service function. It could be interesting for future research to investigate how the perception of customers and management differs in regards to the effect of apology as the interaction justice based service recovery. Fourthly, service recovery with apology might impact differently on consumer future intentions over time. As such, mangers need to develop a follow up strategy to identify the impact of apology as it may not be reflected through consumer reaction immediately.

Further, this was the first study in which failures were varied based on their types. The findings of this study do not support the existing studies where service failures were not categorised into process and outcome types. This contradiction of research findings seems to complicate the design of recovery strategy. Finally, this study was conducted within hospitality service failure settings. Service processes vary across industries and they may not be identical in regards to consumer perception of service performance between hospitality and other service sectors. There is a need to replicate this study in other industry settings to determine if the results are generalisable.

\section{References}

Andreassen, T. W. (2001). "From disgust to delight: Do customers hold a grudge?" Journal of service research, 4(1), 39-49.

Bailey, D. (1994). "Recovery from customer sortfall. Managing Service Quality", 4(6), 25-37.

Bamford, D., \& Xystouri, T. (2005). "A case study of service failure and recovery within an international airline". Managing Service Quality, 15(3), 306-332.

Barnes, M. L., \& Eagles, P. (2004). "Examining the relationship between ecotourists and philanthropic behaviour". Tourism Recreation Research, 29(3), 35-38.

Boshoff, C., \& Leong, J. (1998). "Empowerment, attribution and apologising as dimensions of service recovery: An experimental study". International Journal of Service Industry Management, 9(1), 2447.

Boshoff, C., \& Leong, J. (1998). "Empowerment, attribution and apologising as dimensions of service recovery: An experimental study". International Journal of Service Industry Management, 9(1), 2447.

Brown, S. W. (2000). "Practicing best-in-class service recovery. Marketing Management", 9(2), 8-9.

Dabholkar, P. A., \& Overby, J. W. (2005). "Linking process and outcome to service quality and customer satisfaction evaluations". International Journal of Service Industry Management.16( 1), 2005.pp. 10-27.

Day, R. (1980). "Research perspectives on consumer complaining behavior", in Theoretical Developments in Marketing. Paper presented at the American Marketing Association, Chicago, IL.

Duffy, J. A. M., Miller, J. M., \& Bexley, J. B. (2006). "Banking customers' varied reactions to service recovery strategies". International Journal of Bank Marketing, 24(2), 112-132.

Edvardsson, B., \& Roos, I. (2003). "Customer Complaints and Switching Behavior- A study of relationship dynamics in a telecommunication company". Journal of Relationship Marketing, 2(1/2), 43-68.

Grace, D., \& O'Cass, A. (2001). "Attributions of service switching: a study of consumers' and providers' perceptions of child-care service delivery". Journal of services marketing, 1 5(4), 300 321. 
Griffin, J.-B., \& Lowenstein, M. W. (2001). “Customer Winback: How to Recapture Lost Customers and Keep them Loyal". San Francisco.

Hart, C. W. L., Hesket, J., \& Sasser, W. E. (1990). "The Profitable art of service recovery". Harvard Business Review, 68(4), 148-156.

Heung, V. C. S., \& Lam, T. (2003). "Customer complaint behaviour towards hotel restaurant services". International Journal of Contemporary Hospitality Management, 15(5), 283-289.

Hocutt, M. A., Bowers, M. R., \& Donavan, D. T. (2006). "The art of service recovery: fact or fiction?" Journal of Services Marketing, 20(3), 199-207.

Johnston, R., \& Fern, A. (1999). "Service recovery strategies for single and double deviation scenarios". The Service Industries Journal, 2, 69-82.

Kanousi, A. (2005). "An empirical investigation of the role of culture on service recovery expectations". International Journal of Service Industry Management, 16(1), 10-27.

Keaveney, S. M. (1995). "Customer switching behavior in service industries: An exploratory study". Journal of Marketing, 59(2), 71-82.

Kelley, S. W., Hoffman, K. D., \& Davis, M. A. (1993). “A typology of retail failures and recoveries". Journal of Retailing, 69(4), 429-451.

Kim, C., Kim, S., Im, S., \& Shin, C. (2003). "The effect of attitude and perception on consumer complaint intentions". Journal of consumer Marketing, 20(4), 352 - 371.

Lee, C. C., \& Hu, C. (2004). “Analyzing hotel customers' e-complaints from an internet complaint forum”. Journal of Travel \& Tourism Marketing, 17(2/3), 167-181.

Lewis, B. R., \& Spyrakopoulos, S. (2001). "Service failures and recovery in retail banking: the customers' perspective". The International Journal of Bank Marketing, 19(1), 37-47.

Liu, B. S.-C., Sudharshan, D., \& Hamer, L. O. (2000). "After-service response in service quality assessment: a real-time updating model". Journal of Services Marketing, 14(2/3), 160-176.

Lovelock, C. H., Patterson, P. G., \& Walker, R. H. (2001). "Services Marketing: An Asia-Pacific Perspective". Sydney: Prentice-Hall/Pearson Education Australia.

Mattila, A. S. (2001). "The effectiveness of service recovery in a multi-industry setting". The Journal of Services Marketing, 15(6/7), 583-596.

Maxham III, J. G., \& Netemyer, R. G. (2003). "Firms reap what they sow: The effects of shared values and perceived organizational justice on customers' evaluations of complaint handling". Journal of Marketing, 67(1), 46-62.

Ndubisi, N. O., \& Ling, T. Y. (2005). "Complaint behaviour of Malaysian consumers".School of Business, Monash University Malaysia. Management Research News, 29(1/2), 65-76.

Ojasalo, J. (2001). "Managing customer expectations in professional services". Managing Service Quality, 11(3), 200.

Palmer, A., Beggs, R., \& Keown-McMullan;, C. (2000). "Equity and repurchase intention following service failure". The Journal of Services Marketing, 14(6), 513-528.

Parasuraman, A., Berry, L. L., \& Zeithaml, V. A. (1991). "Refinement and reassessment of the SERVQUAL scale". Journal of Retailing, 67(Winter), 420-450.

Parasuraman, A., Zeithaml, V. A., \& Berry, L. L. (1988). "SERVQUAL: a multiple-item scale for measuring consumer perceptions of service quality". Journal of Retailing, 64(Spring,), 12-40.

Patterson, P. G., \& Smith, T. (2001). "Modeling relationship strength across service types in an Eastern culture". International Journal of Service Industry Management, 12(2), 90-113.

Poon, W.-C., \& Low, K. L.-T. (2005). "Are travellers satisfied with Malaysian hotels"? International Journal of Contemporary Hospitality Management, 17(3), 217-227.

Ranaweera, C., \& Prabhu, J. (2003). "The influence of satisfaction, trust and switching barriers on customer retention in a continuous purchasing setting". International Journal of Service Industry Management, 14(4), 374-395.

Reardon, J., \& McCorkle, D. E. (2002). "A consumer model for channel switching behavior". International Journal of Retail and Distribution Management, 30(4), 179-185.

Schoefer, K., \& Ennew, C. (2004). "Customer evaluations of tour operators' responses to their complaints”. Journal of Travel \& Tourism Marketing, 17(1), 83-92. 
Shapiro, T., \& Nieman-Gonder, J. (2006). "Effect of communication mode justice-based service recovery". Managing Service Quality, 14(2), 124-144.

Snellman, K., \& Vihtkar, T. (2003). "Customer complaining behavior in technology-based service encounters". International Journal of Service Industry Management, 14(2), 217-231.

Snellman, K., \& Vihtkar, T. (2003). "Customer complaining behavior in technology-based service encounters”. International Journal of Service Industry Management, 14(2), 217-231.

Sparks, B. A., \& McColl-Kennedy, J. R. (2001). "Justice strategy options for increased customer satisfaction in a services recovery setting". Journal of Business Research, 54(3), 209-208.

Stauss, B. (2002). "The dimensions of complaint satisfaction: process and outcome complaint satisfaction versus cold fact and warm act complaint satisfaction". Managing Service Quality, 12( 3), 173-183.

Swanson, S. R., \& Kelley, S. W. (2001). "Attributions and outcomes of the service recovery process". Journal of Marketing Theory and Practice, 9(4), 50-65.

Tax, S., Brown, S. W., \& Chandrashekaran, M. (1998). "Customer Evaluation of Service complaint experience: Implication for relationship marketing”. Journal of Marketing, 62(2), 60-76.

Thomas, J. S., Blattberg, R. C., \& Fox, E. J. (2004). "Recapturing Lost Customers". Journal of Marketing Research (JMR), 41(1), 31-45.

Williams, R., \& Visser, R. (2002). "Customer satisfaction: it is dead but it will not lie down". Managing Service Quality, 12(3), 194-200.

Wirtz, J., \& Mattila, A. S. (2004). "Consumer responses to compensation, speed of recovery and apology after a service failure". International Journal of Service Industry Management, 15(2), 150166.

Zekme, R., \& Bell, C. (1990). "Service recovery: Doing it right the second time". Training, 27(6), 4248.

Zhu, Z., Shivkumar, K., \& Parasuraman, A. (2004). “A Mathematical Model of Service Failure and Recovery Strategies". Decision Sciences, 35(3), 493-525.

Zikmund, W. G. (2003). "Exploring Marketing Research". Thomson Learning, USA. 